\title{
Illness and the Politics of Social Suffering: Towards a Critical Research Agenda in Health and Science Studies
}

Doença e política do sofrimento social: para uma agenda de investigação crítica nos estudos da saúde e da ciência

Maladie et politique de la souffrance sociale: pour un agenda de recherche critique dans les études de la santé et de la science

\section{Tiago Pires Marques}

\section{OpenEdition}

\section{Journals}

Electronic version

URL: http://journals.openedition.org/rccs/7763

DOI: $10.4000 /$ rccs. 7763

ISSN: 2182-7435

Publisher

Centro de Estudos Sociais da Universidade de Coimbra

Printed version

Date of publication: 7 November 2018

Number of pages: 141-164

ISSN: 0254-1106

\section{Electronic reference}

Tiago Pires Marques, «IIIness and the Politics of Social Suffering: Towards a Critical Research Agenda in Health and Science Studies », Revista Crítica de Ciências Sociais [Online], Número especial | 2018, Online since 05 November 2018, connection on 01 May 2019. URL : http://journals.openedition.org/ rccs/7763 ; DOl : $10.4000 /$ rccs. 7763 


\section{Illness and the Politics of Social Suffering: Towards a Critical Research Agenda in Health and Science Studies*}

This article analyses some of the emerging problems in the field of social studies at the juncture of the domains of health and science. Building on critical perspectives, namely those hailing from social history, postcolonial studies and collaborative research, it argues for the need to ground investigation on concrete historical forms of social suffering. This implies a multi-scale approach which considers: 1) individual suffering and illness experienced in social interactions; 2) the institutionalised expert translations of suffering into disease; and 3) the political rationales, developed by both local and global stakeholders, which assist in the creation of social environments of health and illness. While illustrations of the theoretical proposals derive mostly from the particular field of mental health, it is argued that their implications may apply to a wider range of themes dealing with health and science issues.

Keywords: healthcare; health governance; illness; mental health; sociology of health; suffering.

The fields of health and science studies, respectively, have vast sets of problems, the exploration of which has developed from various disciplinary and methodological traditions, involving different epistemologies (Nunes and Roque, 2008; Bastos, 2008; Rogers and Pilgrim, 2014; Carapinheiro and Correia, 2015). In order to map the research questions at the intersection

\footnotetext{
* Acknowledgments: I am grateful to the anonymous reviewers for their valuable suggestions; to the colleagues at Centre for Social Studies of the University of Coimbra (Portugal) with whom I worked on health and science studies over the last four years; and, in particular, to Sílvia Portugal, who, through our endless discussions on many of these topics, contributed immensely to the reflections presented in this article.

In addition, I gratefully acknowledge the financial support within the research project "The Fabric of Mental Health. Medical Power, Secularity, and the Psychotherapeutic Field in Portugal (1940s-1990s)" (IF/01589/2013/CP1164/CT0005) and the Strategic Programme (UID/ /SOC/50012/2013), of the Portuguese Foundation for Science and Technology.
} 
of these fields, a possible strategy to adopt would be that of the exhaustive investigation of the emerging issues at the frontier between the production of specialised scientific knowledge, namely genetics and new biotechnologies, and the variations of definitions of health and disease. This would lead to the proposals aiming to build on the idea that the diversity of scientific, medical and epidemiological technologies and practices produces diverse ways of accessing the reality of a given disease. According to the concept advanced by Annemarie Mol, one of the leading scholars contributing to this epistemological proposal and usually referred to as the ontological turn, different ways of performing a disease coexist without overlapping or suppressing one another. Following this line of thought, researchers working at the intersection of science and health studies would undertake the mission of observing how scientists, in the production of knowledge on diseases, make choices and operationalise practices determinant of the many ontological modalities of such diseases (Mol, 2008). However, this way of depicting the field could well lead to a somewhat disjointed panorama of topics, inevitably disconnected from the historical contexts that enhance the construction of perspectives critical of the prevailing forms of social domination.

Thus, although this reference to other epistemological options strikes me as necessary, along with the recognition of their validity and even of their critical potential, I propose an anchorage of research objects, not in laboratorial or hospital life, but in the historical experience of disease (and health). This option led me to consider, for each domain of problems, several degrees of generality. Concretely, in each section I address a specific field of problems, starting from socio-historical issues observed and raised in the contemporary scientific literature. Mostly, these concern the more specific field of mental health, from which I draw the majority of examples. At the end of each section, I address a few potentially generalisable questions.

\section{Bodies, Context and Text}

Let us first define the basic coordinates of this reflection. If there is a point of agreement in the immense literature on health in social science research, it concentrates on the idea that suffering and illness are both bodily and social experiences. Without considering some of the conceptual subtleties of the investigation attentive to the processes of embodiment, this idea would be trivial. Firstly, we need to distinguish the concept of embodiment from the notion that the body and the individual constitute the sites, or the causes, of illness and health (Carapinheiro and Correia, 2015: 1). Indeed, through this concept, it is generally meant that individual bodies suffer in interaction with other bodies and objects (Turner, 1992; Csordas, 2002). Secondly, 
the experience of suffering occurs in cultural contexts; as such, it is shaped by, and expresses, social meanings. This idea has been the object of particular attention in the field. As an example, medical anthropologists in the last few decades have explored the concept of idioms of distress to make sense of the idea that suffering and illness are experienced through cultural repertoires (Crapanzano, 1985; Kleinman and Good, 1985; Kleinman 1988). ${ }^{1}$ In other words, bodily experiences, symptoms and accounts of illness are relational and meaningful experiences. Embodiment is eminently individual, but, it is no less a social and cultural process.

In order to operationalise the idea that bodily phenomena of distress and illness are not simply individual matters, I recur to the concept of social suffering as proposed by Arthur Kleinman and Joan Kleinman. Taking stock of years of research on the social determinants of illnesses and their cultural idioms, these medical anthropologists build the concept on two ideas: 1) social interactions, historically situated, are constitutive of the experiences of pain, disorder and illness; 2) collective forms of experience, i.e. the more or less coded models of suffering, shape the perceptions and expressions of individual suffering (Kleinman and Kleinman, 1997: 2). Recalling Ian Hacking's critique of the now trivialised versions of social constructivism, it is important to emphasise here that none of this means that illness and health are merely social constructs, that is, contingent, disembodied, discursive facts (Hacking, 1995, 1999). Illness and health are social, just as they are biological and molecular. In other words, what is at stake in the appropriation of health and illness as objects of the social sciences is not - or should not be - their subtraction to biology, but rather the claim that embodied biological phenomena are part of the social game of interactions (in this line of thought, see Santos, 1995).

This definition of social suffering defers to different phenomena. One concerns the emergence of illness experiences in the lives of individuals: a certain suffering manifests itself in ways that the suffering individual considers abnormal or pathological. In this process, suffering may be redefined as illness. Another definition regards the work of collective and individual production of meanings around the experiences of suffering and illness. These two phenomena are actually interdependent: experiences of suffering and illness come into being in a variety of ways, reflecting cultural meanings, scientific concepts diffused in societies, meanings derived from clinical observations, as well as those emerging from a variety of

${ }_{1}$ The journals Transcultural Psychiatry (McGill University) and Medicine, Psychiatry and Culture (Harvard University) have been particularly vocal of the cultural "idioms of suffering" approach. 
prevention, treatment and care interventions. Thus, suffering and a wide plurality of meanings interact in processes with a looping effect. As an example, fibromyalgia and other somatoform disorders seem to be, at least initially, sufferings in search of repertoires of symptoms by means of which the suffering individuals seek to construct a performativity capable of eliciting the recognition of their suffering by others (namely, by experts) (Greco, 1998; Quartilho, 2016). Yet, despite this close interdependence, it seems possible to differentiate two areas of problems: the emergence of illness experiences in the life of individuals, and the work undertaken by authorized experts to identify the underlying health issue, restore health or help coping with the illness (or disease). ${ }^{2}$

These two dimensions of social suffering and the interlinked illness experiences are eminently individual and interactional. However, they do not exhaust the production of meanings relative to suffering and illness, and therefore the production of health. In the light of the fact that illness experiences and expert interventions are themselves located in social and institutional sites and built on shared representations and values, we must consider yet another level of phenomena as significant for the production of health and illness. This regards the ways in which a multiplicity of actors intervening in governance and the public space produce values of health and care. In fact, by means of political agendas, institutional reforms, market regulations (or lack thereof), as well as their presence in the media, legitimised actors in the health field convey representations and values regarding the health of individuals and populations. These values and representations shape the possibilities of translating suffering into illness and, consequently, their greater or lesser social recognition (medical, institutional, cultural). I will designate this third plan of analysis the political ecology of health.

Thus developed, the concept of social suffering allows one to configure the field of problems placed under the aegis of science and health studies along the following three dimensions: 1) the forms of suffering articulated as lived illness experiences (Social suffering/Individual pathologies); 2) the legitimized cultural work oriented towards the translation of suffering

\footnotetext{
${ }^{2}$ The sociology of health incorporated into its shared conceptual tools the linguistic distinction in English between "illness", that is, the pathology in the terms of the "ill person", deferring to the subjective experience of the patient; and "disease", the pathology in the terms of medicine, conveying the medical definitions and etiologies of the pathology. We may add the concept of "sickness", resonating the wider cultural meanings associated with the illnesses and diseases (for the field of mental health, see Kleinman, 1988; more generally in the sociology of health, Carapinheiro and Correia, 2015: 6-7).
} 
into diseases (The expert constitution of diseases); 3 ) and the political production of institutions, values and representations of health (The political ecology of bealth).

\section{Social Suffering/Individual Pathologies}

Contemporary forms of suffering would be incomprehensible without taking into account the historical processes of industrialisation, the development of capitalist economies, and the secularisation dynamics structuring contemporary societies. In their various historical forms, these processes have become increasingly globalised, transforming both societies and the world profoundly. Although concomitant, or allied, with significant cognitive and technological achievements over the past two centuries, these processes have also fostered endemic and growing inequality as well as a variety of negative impacts on the life sphere of individuals. A number of historical forms of capitalism, in particular, have multiplied the forms of exclusion. Although many other sources of suffering are related with health - biological, social and environmental - let us focus here on those more tightly linked with contemporary forms socio-economic exclusion and vulnerability. ${ }^{3}$

Among the social scientists devoting their work to modern forms of exclusion, Robert Castel (2011) stands out for closely observing the relationships between the transformations of social suffering, the construction of scientific and medical knowledge, and the forms of governance of the vulnerable populations. The French sociologist placed this analysis under the aegis of the metamorphoses of the "social question", an expression popularised in the second half of the $19^{\text {th }}$ century as a means of expressing political awareness that the economic structures of modernity brought new forms of suffering for large sectors of the population instead of the prosperity and happiness promised to them (Castel, 1995). Castel's account of the history of the social question in the $19^{\text {th }}$ and $20^{\text {th }}$ centuries shows that, from the exclusions associated with urbanisation, industrial development and the contractual regulation of unequal socio-economic relations, the "social question" has undergone several changes. In the late $20^{\text {th }}$ century, apart from extreme poverty, the "social question" concerned a large group of individuals whose social existence is best described as the "useless of the world". Whereas in pre-industrial societies, these were individuals who, by and large, no longer enjoyed the protection of a "lord", a city or a church

\footnotetext{
${ }^{3}$ Vulnerability is to be analysed, of course, in relation with many other health issues, such as infectious diseases and malnutrition related problems, as well as with events such as catastrophes and other forms of exposure to risk (e.g. Kleinman, 1997; Mendes et al., 2011).
} 
(of which that the vagabond was the maximum expression), in industrial and capitalist societies, they were persons engrossed in what Marx called the "wage labour reserve". In the post-industrial and post-employment emerging world, the "useless" are those whose lives unfold on the outside of - or along lines tangent to - the labour markets (Castel, 1995: 753). Since their relationship with the inherited security of the welfare state is, in many cases, equally external or tangent, the survival and well-being of these individuals are constantly threatened.

The mass of suffering individuals of the "social question" in its contemporary form is, to a large extent, constituted by those who, by objective and subjective conditions, find themselves unable to have meaningful lives, of "building a life", instead of merely "making a life", in the words of cultural studies scholar Lauren Berlant (2011). Reminiscent of the critiques of late capitalism linking structural selfish materialism (James, 2008) and the systemic "cancelation of the long term" (Fisher, 2009: 76) with the epidemic of mental illnesses, Berlant makes a compelling argument for an approach to illness in the context of subjects' traumatic encounters with the impossibility of fulfilling their hopes for self-realisation and happiness. Berlant (2011) views these encounters as an outcome of structured socio-political situations functioning through the promotion of impossible fantasies of happiness ("cruel optimism") and an interlinked process of emptying alternative meanings from organized daily life ("life-making"), as well as the disorganisation of life trajectories typical of affluent Western societies ("life-building"). In sum, critical analyses of illness and health must account for the forms of suffering emerging not only in the context of poverty but also in contexts of precariousness, individualism, the dissolution of social support networks, and the erosion of welfare state protections.

Often, bodies suffer these predicaments of social life in ways that anticipate or circumvent language and that resist conceptualization. A few relatively recent medical categories testify to this in an eloquent way, as they explicitly aggregate symptoms unaccountable in the terms of any specific pathology. Let us illustrate this with two examples encountered in biomedical literature, those of "medically unexplained physical symptoms" and "diffuse distress" (sofrimento difuso).

\footnotetext{
${ }^{4}$ For Berlant, these processes, above all, characterise contemporary neo-liberal societies. Faced with the impossibility of constructing meaning, many individuals recur to forms of non-narrative agency ("lateral agency") that Berlant analyses as sensorial readjustments to the breakdown of "life-making" and "life-building". Furthermore, Berlant concretely observes these forms of agency in the current American epidemics of obesity and depression (Berlant, 2011: 100).
} 
The object of a rapidly growing number of scientific articles, "medically unexplained physical symptoms" typically includes, among others, irritable bowel syndrome, non-ulcer dyspepsia, fibromyalgia, and chronic fatigue syndrome. A meta-analytic study on these "four functional somatic syndromes", carried out by the Department of Psychosomatic Medicine at the University of Heidelberg (Germany), aimed at discerning the extent to which these conditions could be viewed as the somatic manifestations of common mental disorders, such anxiety and depression. While the chronic fatigue syndrome could be associated with higher scores of depression than the other syndromes, overall, the study argued in favour of the relative independence of these conditions from mental disorders (Henningsen, Zimmermann and Sattel, 2003).

A few years earlier, observing the specificities of Brazil in the face of globalising health trends, Victor Vincent Valla coined the concept of "diffuse distress", meaning "nonspecific somatic complaints, such as headaches and pain in the body, insomnia, nervousness, gastric problems and distress unclassifiable though psychiatric diagnoses" (apud Fonseca et al., 2008: 286; translation by the author). The concept explicitly implied that the roots of these forms of suffering are typically social, related to the family, employment, and the economic conditions of the poorer classes. Focusing specifically on this population, Valla observed that these symptoms featured prominently among the most common complaints addressed to the health services, which were frequently found unable to respond appropriately (Valla, 2001).

The tendency is for these relatively new conditions to replace the concept of suffering by that of pain, less open to the narrative processes able to articulate meanings that go beyond the strict realm of the disease. While some actors in the health field seem to strategically fight this tendency by linking this and similar conditions with mental disorders, others argue that we should abandon the idea that "underneath pain, fatigue or incapacity lurk medical or psychiatric diseases waiting for due recognition" (Quartilho, 2018: 93; translation by the author). Instead, as argued by Henningsen and Priebe, "we may conceive the referred symptoms as a primary expression between the individual, his/her life objectives and his/her social world" (ibidem). Similar lines of argumentation - that is, ones deferring to direct relationships between social suffering and their pathologies - have been developed with regard to other highly prevalent health issues, such as morbid obesity and depression. These tend to originate more from critical social sciences and cultural studies than from the biomedical field (Ahmed, 2010; Berlant, 2011; Cvetkovich, 2012). In these cases, authors select performative 
and visual arts, as well as non-academic genres, such as autobiographical writings, as the privileged means and genres for conveying embodied social suffering.

In the last two decades, scholars have increasingly encouraged health service users to collaboratively produce materials reminiscent of their experiences. While this methodology represents the particularities of collaborative, and sometimes user-led, research (Turner and Beresford, 2005; Wallcraft et al., 2009; Russo, 2012), the limitations encountered in the production of experiences through research have shed light onto a generalizable problem in health and science studies. Indeed, as Nunes and Siqueira-Silva $(2016,2018)$ rightly observe, it would be best to acknowledge the constructed nature of "experiences" and fully address the often "abyssal" nature of individual suffering. This means that, when faced with life and the experience of reality - and, in particular, with regard to those contexts relative to that which Boaventura de Sousa Santos has identified as "beyond the abyssal lines" of the globalised world (Santos, 2014) - our attempts at "understanding" first-hand experiences may be no more than the acknowledgement of our shared humanity and its fragility. Extreme suffering dehumanises and stretches the limits of the human; in extreme circumstances, in which cognition may no longer be possible, acts of recognition may, instead, take the place of the claim to know, as the cartographic methodologies developed in Brazil seem to imply (Passos et al., 2013).

In sum, we may identify two major challenges for research at the level of lived experience. The first resides in the capacity of making sense of socio-somatic and socio-biographical forms of suffering in alternative to, and in spite of, the objectifying and individualising biomedical forms of knowledge. Life stories addressing illness and other types of suffering narratives in their context seem particularly helpful here.

The second major challenge regards the actual limits of the former endeavour, namely those regarding the production of experiences available for knowledge. In many circumstances, the experience of suffering may pose an "abyssal line" to any form of knowledge enterprise. In these cases, research is to seek other forms of hosting their fellow subjects, embracing the silence of that which cannot be articulated as well. "What we cannot speak about we must pass over in silence" (Wittgenstein, 2001: 89) - Wittgenstein's famous adagio may well serve as a reminder of basic epistemological prudence in the sciences and health studies. Yet, "silence" here must not necessarily imply a contemplative delimitation of an absence (of the possibility to articulate knowledge, for example), but may, instead, 
constitute a form of exposing social research to new engagements with non-verbal forms of presence: bodies, dancing, music, art, cartographic wanderings.

\section{The Expert Constitution of Diseases: The Case of Depression}

The diagnosis of depression constitutes one of the most successful cases of medical and social legitimation of suffering (Pignarre, 2001; Shorter, 2013). For all its important social resonances, its alarming rates of prevalence and embeddedness in modern life (Almeida and Xavier, 2013; WHO, 2017), depression constitutes a remarkable case study of the problems encountered at the frontiers of social suffering and medically defined disease. As depression is generally and historically characterised in terms of symptoms of sadness, hopelessness, lack of vitality and interest in life, withdrawal from social interactions, anxiety and insomnia, it would seem an avatar of concepts such as melancholia, acedia and neurasthenia (Pigeaud, 2008). Yet, as opposed to the latter, depression is deployed in the specific institutional settings of modern psychiatry, neurosciences and psychotherapies, the pharmaceutical industries and their markets, and is the object of medical advertising and public policies. Indeed, the line between normal and pathological reactions to loss, precariousness or traumatic events depends on theoretical conventions, diagnostic techniques, therapeutic tools and styles of clinical thinking typical of Global North countries (Young, 1997; Horowitz and Wakefield, 2007). According to Alain Ehrenberg, one of the most prominent scientists studying mental health from a sociological perspective, depression reflects increased demands on the individual, namely the injunctions of autonomy and performativity and, combined with the vocabulary of addiction, has become a central element in the emotional grammars of modern individualism (Ehrenberg, 2008). Along this line of thought, the vocabularies and practices involving depression and addiction, developed in the advanced capitalist and secular settings of the Global North, and well-rooted in their therapeutic cultures, contribute arguably to promoting individualist emotional grammars.

However, the globalisation of scientific discourses and mental health interventions has been accompanied by the argument (or the growing awareness, as far as "experts" are concerned) that depression constitutes one of the world's most disabling health conditions (WHO, 2017). Here, opinions divide as to whether this observation results from changing concepts of mental disorder promoting the medicalisation and pharmaceutisation of life (Illich, 1982; Turner, 1992; Conrad, 2007; Whitaker, 2010) or, rather, the public articulation of a new vocabulary generating a better recognition 
of social suffering. Anthropological studies on emotions and distress in societies remaining in the periphery and semi-periphery of mental health knowledge have shown that the expression of emotions exhibits different styles in different populations; accordingly, these populations also present a variety of ways of organising distress (Kleinman and Good, 1985; O'Nell, 1998). Kleinman (1988) and Littlewood (2002) explored the clinical and moral consequences of the decontextualisation of psychiatry in America and Europe. As for depression, Littlewood showed how the psychiatric nosology and epidemiology reflected implicit notions of personhood (a strongly fenced sense of the self), responsibility (the ideal of the autonomous self), and gender (depression being diagnosed in women at considerably higher rates) (Littlewood, 2002: 8-12, 146-149). Along this line of thought, the expert production of Western "mental disorders" in many societies of the Global South, for example, would amount to the medicalisation of life as well as a form of neo-colonisation (e.g. Pandolfo, 2008; Pinto, 2008).

This issue is all the more important as it is now widely accepted that, in many cases, diagnoses, rather than merely being concepts circumscribed to doctor/patient relationships and biomedical settings, have become part of patients' sense of self. As a number of authors have shown, depression has become deeply entangled in the complex structure of culture and their personal lives (Alves, 2011; Castel, 2012). In some cases, as, for example, those manifest in the more serious form of bipolar disorders (Martin, 2007), depression integrates new individual and collective identities, a process that Nikolas Rose analysed as the constitution of "biosocial identities" (Rose, 1996, 2007). ${ }^{5}$

These analyses seem to imply that medicalisation of life reaches deep into the self, suggesting that it alienates individuals from social struggles. However, recent studies point to more complex entanglements of biosocialities and political agency. A fine illustration of this can be found in the study by anthropologist Junko Kitanaka on the spread of the Western grammar of depression in Japan, which has greatly improved the quality of the debate on these problems. Kitanaka argues that rather than merely effecting the medicalisation and individualisation of suffering, the psychiatric grammar of depression, fundamentally alien to the Japanese culture for its consideration of social determinants (rather than solely biological), subversively questions the Japanese social order in which the depressed persons live.

\footnotetext{
${ }^{5}$ Rose developed a Foucauldian approach to bio-power in observing the relationship between governance exercised through means of biotechnologies and the emergence of "biosociabilities", i.e., of identities structured around medical categories or practices (Rose, 1996, 2007).
} 
Concretely, the psychiatric language of depression is deemed to transform the positive values often linked to depressed behaviour - e.g. suicide as normal or even honourable - and to shed light onto the (unjust) social pressures placed on individuals (Kitanaka, 2012: 194-195).

In sum, this "ground-up medicalisation" of distress (and of life) may also be experienced and used as a protection against a perceived alienating social order. The above-mentioned discussions on medically unexplained physical symptoms and, in Brazil, around "diffuse distress" - in both cases with mental health experts arguing for their links with depression and anxiety - may well point to similar rationales. Indeed, we may read these debates as part of individual and collective processes oriented towards an expert, biomedical recognition of suffering as a means of eliciting some sort of social and political protection.

In other cases, lay and expert appropriations of categories such as "depression" may also defer to strategies aimed at the protection of persons suffering social pressures considered unacceptable, but not necessarily through their medicalisation. This seems to be the case with semi-peripheral societies, such as Portugal and Greece. In a study on the lay rationalities regarding psychic suffering and mental illnesses in Portugal, sociologist Fátima Alves observes that folk concepts used to express these phenomena, namely "nervos", "cismas" and "doenças da cabeça" (translatable as "nerves", "obsessions", "head diseases”), are imbued with strongly negative moral meanings. In fact, these categories, whether or not combined with notions of a biological causality, defer to a fundamental "weakness of character". The exception seems to be exactly that of "depression": at the frontier of normal mental suffering and mental illness, depression emerges in lay discourses as a product of the pressures and contradictions of the consumerism and individualism of the modern society (Alves, 2011: 168).

In Greece, anthropologist Athéna Peglidou, focusing on depression among Greek women during the 2000s, observes that depressive-like symptoms and behaviour reflect the fragility of women's positions in a predominantly patriarchal society. Thus, similar to what is seen in Portugal, the concept lends itself to a reflection on the social determinants of suffering and illness. Looking at the strategies women deploy to recover from depression, Peglidou argues that this clinical vocabulary may constitute a tool with which they attempt to obtain a stronger grip on their lives (Peglidou, 2004).

Additionally, these two cases show that the strategies for coping with depression frequently involve a bricolage of medical practices and religious rituals, a feature that may be particularly characteristic of semi-peripheral societies (ibidem). Unlike Japan (and other central European 
countries), ${ }^{6}$ and, to a certain extent also unlike Brazil, the concept of depression is weakly politicised. Indeed, in Portugal, the few sociological studies on psychiatric care are indicative of how only one's family and the recourse to religiously-affiliated professionals remain key in the individual and social management of suffering (Alves, 2011; Hespanha et al., 2012; Portugal, 2016). In this way, the fragility of the welfare state - and here also of civil society and, relatedly, the weak politicisation of social issues - is thus compensated by a strong "welfare society" (Santos, 1994).

To summarise, at this level of analysis, research ought, firstly, to take into account the fact that the expert production of diseases reflects high-intensity globalisation processes. However, far from creating homogeneous realities, their impact varies according to local determinants and the ways in which these relate with the globalising idioms of health. The former reflects the varying combinations of the types of knowledge mobilised - biomedical, alternative expert knowledge, and lay forms of experiential knowledge. The latter obliges us to consider differences within the globalized language of biomedical expertise as well.

Secondly, some illnesses have emerged typically as "diseases of modernity". Some cancers, heart diseases, obesity, diabetes and mental disorders, such as depression and burn-out, are just a few examples among many possible others. Because of their strong social resonances, their diagnosing and treatment mobilise values and representations that much transcend the exercise of medicine. While value-centred approaches, as opposed to evidence-based medicine, are making their way in mental health (Fulford, 2004), we are likely to witness comparable movements in other health sectors (Carapinheiro, 2011). This may be particularly manifest in processes that initially strike us as part of the observed medicalisation of life. Indeed, rather than simply observing the increased use of medical diagnoses to convey social suffering, we are also to pay particular attention to bow they are used in social struggles.

\section{The Political Ecology of Health}

In her argument on the political dimension of depression in Japan, Kitanaka emphasizes the fact that, instead of being a local occurrence, the politicisation of depression is "part of the global movement happening in many nations to protest alienation in the workplace". She adds that,

\footnotetext{
${ }^{6}$ Kitanaka provides bibliography supporting this argument for number of European countries, namely Finland, Italy, Germany and France (Kitanaka, 2012: 197).
} 
[b]y linking depression to the "social ills" brought by neoliberalization - including the perils of privatization, the collapse of lifetime employment, and the crisis in national health care - people seem to be addressing their sense of alienation as real and concrete, as something that requires resolution through political intervention. (Kitanaka, 2012: 197)

While this analysis signals the politicisation of that which Nikolas Rose has called biosocialities, i.e. their use as a political tool - and thus more than just an identity - these movements remain marginal in face of the hegemonic forms of public health.

In fact, the intensification of the globalisation of capitalism and neoliberal policies, combined with the erosion of the welfare state, have generated not only new forms of social suffering but also new forms of governance. The latter operate predominantly through psychosocial and risk minimisation interventions, particularly through health prevention programs as well as the promotion of welfare markets. The complex relationship between the management of the social risks represented by the "vulnerable", the search for a compromise between productivity and the well-being of populations, and the dynamics of the transnational markets for therapies and drugs constitute one of the key sectors of government for new forms of social suffering (Lakoff, 2006; Castel, 2011; Whitaker, 2010).

More concretely, the globalisation of social suffering goes hand in hand with attempts to globalise the governance of social vulnerability, or, in Robert Castel's terminology, with attempts to globalise risk management. Again, mental health may serve as an observatory of these processes. The emerging field of so-called Global Mental Health brings together the specialists and stakeholders that directly intervene in public health and determine government objectives, institutional reform policies and preventive measures. This field registers a centre, located in the North Atlantic, a periphery incorporating middle and low-income countries of the Global South, as well as a semi-periphery (e.g. European contexts that are recipients of models from the centre) (Summerfield, 2012; Kirmayer and Pederson, 2014; Marques, 2017b). By actively promoting agendas of mental well-being, international agencies and institutions such as the United Nations, the World Health Organization (WHO) and the European Union, among others, have contributed to bringing mental health into the spotlight of political and public attention. But so have a number of non-governmental organisations working worldwide, many of them particularly devoted to promoting "mental health" in peripheral and semi-peripheral countries (Lakoff, 2006; Kirmayer and Pederson, 2014). To these global actors, we must 
add the large pharmaceutical industries. Besides their virtual impact on the classification of new mental disorders, especially in the case of Big Pharma, ${ }^{7}$ these global actors also help shape the ways in which knowledge on so-called mental disorders is constructed. Indeed, they promote inquiries and epidemiological reports and provide guidelines to tackle the problems diagnosed (Marques, 2017b). In sum, Global Mental Health actors foster new institutional, epistemological and, by disseminating their concepts and values in societies, cultural environments, in which certain forms of social suffering are validated (or not) as mental diseases deemed to capture political attention. These agents tend to become the authorised translators at the local level of social suffering as a public health issue.

While the globalisation of Western psychiatry and its allied pharmaceutical industry is undeniable, at least since the early 1990s, we can trace a comparable phenomenon of globalising patient movements contesting the conventional biomedical responses. Again, in the mental health domain, these latter movements consist of a plurality of grassroots mobilisations, thus, organised individuals that share an experience of suffering in common alongside contact with psychiatry that they grasp as traumatic and dehumanising. The notion of "first-hand experiences" constitutes the foundations of these collective challenges to psychiatry and to the stigma associated with "mental illness" categories. The reclaiming of experience as a legitimate source of knowledge differentiates these movements from the anti-psychiatry of the 1960s and 1970s, as well from other radical movements advocating psychiatric reform (Turner and Beresford, 2005; Russo and Sweeney, 2016). All of these grassroots movements call for the right to refuse psychiatric treatment, in particular coercive treatments. Many, but not all, reject the concept of "mental illness". And some, but not all, call for the category of "madness" as constitutive of their identities and a legitimate and even enriching part of humanity (LeFrançois et al., 2013). Such a demand becomes most blatantly clear, for example, in the Mad Pride events held in countries such as Canada, Ireland, the United Kingdom, France, the United States, Ghana, Brazil and Chile. ${ }^{8}$

\footnotetext{
7 According to some of its critics, the Global Mental Health movement displays an excessive level of proximity to the pharmaceutical corporations and furthermore contributes to a global trend of pharmacizing suffering (Biehl, 2005; Lakoff, 2006; Dummit, 2012; Healy, 2004; Healy, 2012).

${ }_{8}$ These Mad Pride events typically consist of marches featuring persons with psychiatric diagnoses, family, friends and supporters, whose objective is to counter the stigma associated with psychiatric treatment, affirming therapeutic self-determination and calling for the recognition of their rights as citizens.
} 
Since the 1990s, these grassroots mobilisations have taken on more structured forms through the development of local, national and transnational organisations of "survivors" and "psychiatric service users". For example, the local associations of the Hearing Voices groups, which emerged in the Netherlands but are now present across various continents, organise meetings for sharing the experiences of hearing voices and other phenomena more generally interlinked with pathologies included on the spectrum of psychoses (Intervoice International, 2018). In a similar fashion, transnational organisations such as MindFreedom, the European Network of (Ex-) Users of Psychiatry and GAMIAN-Europe support local organisations that foster inter-peer support, the defence of rights and user-led alternatives to psychiatry (ENUSP, 2018; Gamian-Europe, 2018).

Within this context, proposals have recently focused on establishing an academic field, Mad Studies, based on the concept of "expertise by experience" and alongside an emancipatory questioning of the experiences of suffering and contact with psychiatry. Seeking to evolve from object to the active subject of knowledge, such advocates have sought to establish theories of madness and suffering free of any biomedical assumptions (LeFrançois, Menzies and Reaume, 2013; Russo and Sweeney, 2016) in conjunction with undertaking research defined and produced by former psychiatric patients and "survivors" (Russo, 2012). Some of these grassroots movements have also attempted to have their voices heard within the national and international contexts responsible for defining mental healthcare policies. Thus, running up against the hegemony of medical power and the Global Mental Health movement, these transnational organisations and the local, national and regional grassroots movements arguably foster a counter-hegemonic globalisation in the mental health field.

The emergence of globally connected patient associations may be observed across a vast spectrum of health issues, along with the corresponding health democracy, citizenship and epistemic claims (Akrich et al., 2009; Serapioni and Matos, 2014; Carapinheiro and Correia, 2015). In this context, healthcare has emerged as an arena for competing fundamental values, styles of knowledge and political rationales. The impact made by patient associations and other lay actors on the quality of the government of health institutions and healthcare delivery may indeed prove more complex than a linear improvement through democratisation. Enabled by the development of rationales of governance, with its implications of state-free self-management, the co-opting of patient and lay knowledge, while creating new opportunities for the health democracy, may also open the door to the privatisation of care and the reproduction of social inequalities, including varying degrees in the access to scientific knowledge. 
Along these lines, some authors have argued that the models developed under the labels of "health democracy", "health governance", and "care" are neither ethically nor politically neutral (Castel, 2011; Paperman and Laugier, 2011; Marques, 2017a, 2017b). For example, the hegemonic discourse of governance, in some cases implemented in public hospitals in the form of clinical committees, implies the delegation of competences hitherto allocated to political entities (Orfali, 2003; Marques 2017a). Their legitimacy is based on the technical and institutional complexification of health services and responds to the "health democracy" ethos. However, it may be argued that, in welfare state structures, these competences were more easily become the target of democratic scrutiny. It is, therefore, not clear whether these new forms of public government actually boost responsibility and the democratic rationales they themselves claim (Calame, 2003; Kazancigil, 2010).

At this point, I would like to propose three main scientific challenges emerging from the above discussion. Firstly, it is worth acknowledging that, far from circumscribed to the laboratory and clinical settings, the issues involving science and health are an integral part of social life today. In some cases, contentions about the legitimacy of certain medical labels and interventions actually constitute the privileged locus in which the fundamental questions of life and politics are discussed.

Secondly, and as result of the former process, science and medicine have entered the construction of modern identities and the ways to respond to social suffering. A now vast literature hailing from a variety of critical perspectives observes these occurrences as products of hegemonic biomedical powers. The concepts of biopower and biosocialities encapsulate much of the sociological discussions on identities constructed through biogenetic and/or medical vocabularies. In addition, notions such as medicalization, biomedicalisation ${ }^{9}$ and pharmaceutisation of life are oriented towards the description of processes of addressing the difficulties of life, including forms of suffering hitherto described predominantly as social. However, the political appropriation of biosocialities and medicalisation (and virtually, of pharmaceutisation) of life complicate considerably the debates on the relationship between the biomedical sciences and social emancipation. As we have seen, ground-up medicalisation processes, either in the context of grassroots movements or in collaboration with professionals, may integrate

\footnotetext{
${ }^{9}$ Biomedicalization refers to the transformations of the processes of medicalization of life under the impact of the more recent technosciences, such as genetics, molecular biology and pharmaceuticals, and their effects of the concepts of life and on "life itself" (Clarke, 2003; Clarke et al., 2010).
} 
strategies to face social injustice. Therefore, new scientific questions are required to face these increasingly complex social processes.

Thirdly, much of these dynamics occurs on a global scale and involves a variety of actors. Global healthcare stakeholders range from state agencies to non-governmental organisations, showing different ideologies and outreach capacity, as well as professional and patient associations, companies and international agencies. Many of these share the vocabulary of governance and health democracy. Yet practices are always highly dependent on local contexts and reflect more or less hidden agendas, cultures and values. As a result, it becomes of paramount importance to look at the practical rationales, to employ Pierre Bourdieu's concept (Bourdieu, 1994), observed in the actions of these actors.

All these aspects form that which I called the political ecology of health. While deferring to social processes apparently farther from illness experiences, as well as the immediate responses they elicit, they create the politi$\mathrm{cal}$, institutional and cultural environment structuring both experience and expert responses.

\section{Conclusion}

In the multi-scale approach, this article proposes that individual experience, knowledge construction, and the political and socio-economic production of health together constitute the interlinked dimensions of social suffering. This perspective favours historically sensitive ways of constructing objects, and, as a consequence, research questions reflecting contexts and social relations, rather than topical academic issues or abstract theoretical models. In addition, this approach brings to the centre of the research agenda a radical questioning on both the concept of "experience", namely on its modes of production, limits, and the legitimacy of its appropriation in scientific research (the social sciences included) and on that of "science", as it sheds light on the ways that claims to knowledge, along with their uses and wider meanings, become involved in scientific and political disputes (Nunes, 2012).

Analysis of patient associations, especially when integrating participatory research methodologies, may contribute to the development of the field of applied social sciences. Indeed, participatory research, involving the mobilisation of patient associations and healthcare users in the joint creation of knowledge, holds the potential to questioning the hierarchy of institutionalised knowledge in the health sciences and health care. This may prove useful in view of the recognition of the validity of experience-near forms of knowledge - those of patients/users, lay caregivers and non-medical professionals - virtually more prone than expert knowledge to mobilisation 
in citizenship struggles. Yet, as we have seen, first-hand experiences and expert knowledge are not necessarily antagonistic. In reality, they may be collaborative, with ground-up medicalisation taking socially sensitive and emancipatory orientations, at least in some cases.

Approaches attentive to both expert and non-expert (or experience-based) forms of knowledge are necessary to construct an epistemic space to analyse political identities built around clinical labels (biosocialities), as well as those that diagnosed persons mobilised to contest. This new epistemic space is likely to come forward with new perspectives on the concepts of agency and collective action and contribute towards the scientific and political debate on the relationship between health, rights and citizenship.

Lastly, I have argued that the construction of such an epistemic space sometimes involves competing visions of globalisation. It is namely the case with the globalisation of mental health. Exploratory observations in this field suggest that counter-hegemonic globalisation movements engage knowledge and experiences observed in societies of the Global South. These cover a wide spectrum of issues, from care and recovery practices to strategies for combatting stigma and promoting inclusion. Along this line of thought, the scaling-up of knowledge fostered by grassroots movements promotes new forms of collaborative militancy in which the decolonising of scientific knowledge may find unexpected opportunities.

Edited by Scott M. Culp

\section{References}

Ahmed, Sara (2010), The Promise of Happiness. Durham/London: Duke University Press.

Akrich, Madeleine; Nunes, João Arriscado; Paterson, Florence; Rabeharisoa, Vololona (eds.) (2009), The Dynamics of Patient Organizations in Europe. Paris: Presses de l'École des Mines.

Almeida, José M. Caldas de; Xavier, Miguel (eds.) (2013), Estudo epidemiológico nacional de saúde mental. Lisboa: Faculdade de Ciências Médicas, Universidade Nova de Lisboa.

Alves, Fátima (2011), A doença mental nem sempre é doença: racionalidades leigas sobre saúde e doença mental. Porto: Edições Afrontamento.

Bastos, Cristiana (2008), "Os estudos sobre a ciência, a antropologia e a grande fractura", in João Arriscado Nunes; Ricardo Roque (eds.), Objectos impuros. Experiências em estudos sobre a ciência. Porto: Edições Afrontamento, 107-131.

Berlant, Lauren (2011), Cruel Optimism. Durham, NC: Duke University Press. 
Biehl, João (2005), Vita: Life in a Zone of Social Abandonment. Berkeley/Los Angeles: University of California Press.

Bourdieu, Pierre (1994), Raisons pratiques. Sur la théorie de l'action. Paris: Éditions du Seuil.

Calame, Pierre (2003), La démocratie en miettes. Pour une révolution de la gouvernance. Paris: Descartes et Cie.

Carapinheiro, Graça (2011), "Saúde e doença: um programa crítico de sociologia da saúde”, Sociologia On Line. Revista da Associação Portuguesa de Sociologia, 3(June), 57-71.

Carapinheiro, Graça; Correia, Tiago (2015), "Introdução: diálogos com a sociologia da saúde e da doença”, in Graça Carapinheiro; Tiago Correia (eds.), Novos temas de saúde, novas questões sociais. Lisboa: Mundos Sociais, 1-18.

Castel, Robert (1995), Les metamorfoses de la question sociale. Paris: Gallimard.

Castel, Robert (2011), La gestion des risques. De l'antipsychiatrie à l'après-psychanalyse. Paris: Minuit [orig. 1981].

Castel, Pierre-Henri (2012), La fin des coupables. Obsessions et contrainte intérieure de la psychanalyse aux neurosciences. Volume II: suivi de Le Cas Paramord. Paris: Ithaque.

Clarke, Adele (2003), "Biomedicalization", in William C. Cockerham; Robert Dingwall; Stella Quah (eds.), The Wiley Blackwell Encyclopedia of Health, Illness, Behavior, and Society. Hoboken, NJ: John Wiley \& Sons, 137-142.

Clarke, Adele; Mamo, Laura; Fosket, Jennifer Ruth; Fishman, Jennifer R.; Shim, Janet K. (eds.) (2010), Biomedicalization. Technoscience, Health, and Illness in the U.S. Durham, NC: Duke University Press.

Conrad, Peter (2007), The Medicalization of Society: On the Transformation of Human Conditions into Treatable Disorders. Baltimore: John Hopkins University Press.

Crapanzano, Vincent (1985), Tubami. Portrait of a Moroccan. Chicago/London: The University of Chicago Press.

Csordas, Thomas J. (2002), Body/ Meaning/ Healing. Hampshire/New York: Palgrave McMillan.

Cvetkovich, Ann (2012), Depression: A Public Feeling. Durham, NC: Duke University Press.

Dummit, Joseph (2012), Drugs for Life. How Pharmaceutical Companies Define Our Health. Durham/London: Duke University Press.

Ehrenberg, Alain (2008), La fatigue d'être soi. Dépression et société. Paris: Odile Jacob. ENUSP - European Network for (ex)-Users and Survivors of Psychiatry (2018), "Home". Accessed on 22.03.2018, at http://enusp.org.

Fonseca, Maria Liana Gesteira; Guimarães, Maria Beatriz Lisboa; Vasconcelos, Eduardo Mourão (2008), "Sofrimento difuso e transtornos mentais comuns: uma revisão bibliográfica”, Revista de APS, 11(3), 285-294.

Fisher, Mark (2009), Capitalist Realism. Is There no Alternative? Winchester/ Washington: Zero Books. 
Fulford, Bill (2004), "Neuro-Ethics or Neuro-Values? Delusion and Religious Experience as a Case Study in Values-Based Medicine", Poiesis Prax, 2, 297-313.

GAMIAN-Europe (2018), "Home”. Accessed on 22.03.2018, at http://www.gamian.eu. Greco, Monica (1998), Illness as a Work of Thought. A Foucauldian Perspective on Psychosomatics. London/New York: Routledge.

Hacking, Ian (1995), Rewriting the Soul: Multiple Personality and the Sciences of Memory. Princeton: Princeton University Press.

Hacking, Ian (1999), The Social Construction of What. Cambridge, MA/London: Harvard University Press.

Healy, David (2004), Let Them Eat Prozac: The Unbealthy Relationship Between the Pharmaceutical Industry and Depression. New York/London: New York University Press.

Healy, David (2012), Pharmageddon. Berkeley/Los Angeles: University of California Press.

Henningsen, Peter; Zimmermann, Thomas; Sattel, Heribert (2003), "Medically Unexplained Physical Symptoms, Anxiety, and Depression: A Meta Analytic Review”, Psychosomatic Medicine, 65(4), 528-533.

Hespanha, Pedro; Portugal, Sílvia; Nogueira, Cláudia; Pereira, José Morgado; Hespanha, Maria José (2012), Doença mental, instituições e famílias. Os desafios da desinstitucionalização em Portugal. Coimbra: CES/Almedina.

Horowitz, Allan V.; Wakefield, Jerome C. (2007), The Loss of Sadness. How Psychiatry Transformed Normal Sorrow into Depressive Disorder. Oxford/New York: Oxford University Press.

Illich, Ivan (1982), Medical Nemesis. The Expropriation of Health. New York: Pantheon Books [orig. 1975].

Intervoice International - The Hearing Voices Network (2018), "Home”. Accessed on 22.03 2018, at http://www.intervoiceonline.org.

James, Oliver (2008), The Selfish Capitalist. Origins of Affluenza. London: Vermillion. Kazancigil, Ali (2010), La gouvernance. Pour ou contre le politique? Paris: Armand Collin. Kirmayer Laurence J.; Pederson Duncan (2014), “Toward a New Architecture for Global Mental Health”, Transcultural Psychiatry, 51(6), 759-776.

Kitanaka, Junko (2012), Depression in Japan. Psychiatric Cures for a Society in Distress. Princeton/Oxford: Oxford University Press.

Kleinman, Arthur (1988), Illness Narratives. Suffering, Healing and the Human Condition. New York: Basic Books.

Kleinman, Arthur (1998), Rethinking Psychiatry. From Cultural Category to Personal Experience. New York: The Free Press.

Kleinman Arthur; Good, Byron (eds.) (1985), Culture and Depression: Studies in the Anthropology and Cross-Cultural Psychiatry of Affect and Disorder. Berkeley/Los Angeles: University of California Press.

Kleinman, Arthur; Kleinman, Joan (1997), “The Appeal of Experience; The Dismay of Images: Cultural Appropriations of Suffering in Our Times”, in Arthur Kleinman, 
Veena Das; Margaret Lock (eds.), Social Suffering. Berkeley/Los Angeles/London: Berkeley University Press, 1-23.

Lakoff, Andrew (2006), The Pharmaceutical Reason: Knowledge and Value in Global Psychiatry. Cambridge: Cambridge University Press.

LeFrançois, Brenda A.; Menzies, Robert; Reaume, Geoffrey (eds.) (2013), Mad Matters. A Critical Reader in Canadian Mad Studies. Toronto: Canadian Scholars' Press.

Littlewood, Roland (2002), Pathologies of the West. An Anthropology of Mental Illness in Europe and America. Ithaca, NY: Cornell University Press.

Marques, Tiago Pires (2017a), "Global Mental Health, Autonomy and Medical Paternalism: Reconstructing the 'French Ethical Tradition' in Psychiatry”, History of Psychiatry, 28(3), 326-343.

Marques, Tiago Pires (2017b), “The Policy Gap. Global Mental Health in a Semi-Peripheral Country (Portugal, 1998-2016)", Interface. Comunicação, Saúde, Educação, 21(63), 787-798.

Martin, Emily (2007), Bipolar Expeditions. Mania and Depression in American Culture. Princeton/Oxford: Princeton University Press.

Mendes, José Manuel; Tavares, Alexandre Oliveira; Cunha, Lúcio; Freiria, Susana (2011), "A vulnerabilidade social aos perigos naturais e tecnológicos em Portugal”, Revista Crítica de Ciências Sociais, 93, 95-128.

MindFreedom International (2018), "Home”. Accessed on 22.03.2018, at http://www. mindfreedom.org.

Mol, Annemarie (2008), "Política ontológica. Algumas ideias e várias perguntas", in João Arriscado Nunes; Ricardo Roque (eds.), Objectos impuros. Experiências em estudos sobre a ciência. Porto: Edições Afrontamento, 63-77.

Nunes, João Arriscado; Roque, Ricardo (2008), “Introdução”, in João Arriscado Nunes; Ricardo Roque (eds.), Objectos impuros. Experiências em estudos sobre a ciência. Porto: Edições Afrontamento, 13-35.

Nunes, João Arriscado (2012), “'I Have Become a Microscope for My Own Body’: Local Biologies and the Embodiment of Biomedical Knowledge”, Revista de Antropologia, 29, 65-74.

Nunes, João Arriscado; Siqueira-Silva, Raquel (2016), “Dos 'abismos do inconsciente' às razões da diferença: criação estética e descolonização da desrazão na Reforma Psiquiátrica Brasileira”, Sociologias, 18(43), 208-237.

Nunes, João Arriscado; Siqueira-Silva, Raquel (2018), “Encounter(s): Engaging Suffering across the Abyssal Divide", in Tiago Pires Marques; Mônica Nunes (eds.), Legitimidades da loucura: sofrimento, luta, criatividade e pertença. Salvador, Bahia: Edufba - Editora da Universidade Federal da Bahia, 335-357.

O'Nell, Theresa DeLeane (1998), Disciplined Hearts. History, Identity, and Depression in an American Indian Community. Berkeley/Los Angeles/London: University of California Press. 
Orfali, Kristina (2003), "L'émergence de l'éthique clinique. Politique du sujet ou nouvelle catégorie clinique?”, Sciences sociales et santé, 21(2), 39-70.

Pandolfo, Stefania (2008), "The Knot of the Soul: Postcolonial Conundrums, Madness, and the Imagination”, in Mary-Jo DelVecchio Good; Sandra Teresa Hyde; Sarak Pinto; Byron J. Good (eds.), Postcolonial Disorders. Berkeley/Los Angeles: University of California Press, 329-358.

Paperman, Patricia; Laugier, Sandra S. (eds.) (2011), Le souci des autres. Ethique et politique du care. Paris: EHESS - École des hautes études en sciences sociales.

Passos, Eduardo; Kastrup, Virgínia; Escóssia, Liliana da (2013), Pistas do método da cartografia. Pesquisa-intervenção e produção de subjectividade. Porto Alegre: Editora Meridional.

Peglidou, Athéna (2004), "La gestion de la dépression féminine : une anthropologie de la souffrance psychique à Jannina, en Epire (Grèce)”. Doctoral Thesis in Ethnologie et anthropologie sociale presented to EHESS - École des hautes études en sciences sociales, Paris, France.

Pigeaud, Jackie (2008), Melancholia. Paris: Payot et Rivages.

Pignarre, Philippe (2001), Comment la dépression est devenue une épidémie. Paris: La Découverte.

Pinto, Sarah (2008), "Consuming Grief: Infant Death in the Postcolonial Time of Intervention”, in Mary-Jo DelVecchio Good; Sandra Teresa Hyde; Sarak Pinto; Byron J. Good (eds.), Postcolonial Disorders. Berkeley/Los Angeles: University of California Press, 359-377.

Portugal, Sílvia (2016), "Família e cuidado à doença mental em Portugal”, in Mônica Nunes; Fátima Luna Pinheiro Jardim (eds.), Saúde mental na atenção básica. Política e cotidiano. Salvador: Edufba, 103-121.

Quartilho, Manuel João (2016), O processo de somatização: conceitos, avaliação e tratamento. Coimbra: Imprensa da Universidade de Coimbra.

Quartilho, Manuel João (2018), "Sofrimento e legitimação", in Tiago Pires Marques; Mônica Nunes (eds.), Legitimidades da loucura: sofrimento, luta, criatividade e pertença. Salvador, Bahia: Edufba - Editora da Universidade Federal da Bahia, 59-102.

Rogers, Anne; Pilgrim, Anne (eds.) (2014), A Sociology of Mental Health and Illness. Berkshire: Open University Press. [5 ${ }^{\text {th }}$ ed.; orig. 1993].

Rose, Nikolas (1996), Inventing Ourselves. Psychology, Power, and Personhood. Cambridge/New York: Cambridge University Press.

Rose, Nikolas S. (2007), The Politics of Life Itself: Biomedicine, Power, and Subjectivity in the Twenty-First Century. Princeton: Princeton University Press.

Russo, Jasna (2012), "Survivor-Controlled Research: A New Foundation for Thinking About Psychiatry and Mental Health", Forum: Qualitative Social Research, 13(1), Art. 8. Accessed on 25.01.2017, at http://www.qualitative-research.net/index.php/ fqs/article/view/1790. 
Russo, Jasna; Sweeney Angela (eds.) (2016), Searching for a Rose Garden. Challenging Psychiatry, Fostering Mad Studies. Monmouth: PCCS Books.

Turner, Bryan S. (1992), Regulating Bodies, Essays in Medical Sociology. London: Routledge.

Turner, Michael; Beresford, Peter (2005), User Controlled Research: Its Meanings and Potential. Shaping Our Lives and the Centre for Citizen Participation. London: Brunel University.

Santos, Boaventura de Sousa (1994), Pela mão de Alice. O social e político na pós-modernidade. Porto: Edições Afrontamento.

Santos, Boaventura de Sousa (1995), Um discurso sobre as ciências. Porto: Edições Afrontamento [ $7^{\text {th }}$ ed.].

Santos, Boaventura de Sousa (2014), Epistemologies of the South: Justice against Epistemicide. Boulder, CO: Paradigm Publishers.

Serapioni, Mauro; Matos, Ana Raquel (2014), "Citizen Participation and Discontent in Three Southern European Health Systems”, Social Sciences \& Medicine, 123, 226-233.

Shorter, Edward (2013), How Everyone Became Depressed: The Rise and Fall of the Nervous Breakdown. Oxford/New York: Oxford University Press.

Summerfield, Derek (2012), “Afterword: Against 'Global Mental Health'”, Transcultural Psychiatry, 49(3-4), 519-530.

Valla, Victor Vincent (2001), "Globalização e saúde no Brasil: a busca da sobrevivência pelas classes populares via questão religiosa”, in Eymar Mourão Vasconcelos (ed.), A saúde nas palavras e nos gestos. São Paulo: Hucitec, 39-62.

Young, Allan (1997), The Harmony of Illusions: Inventing Post-Traumatic Stress Disorder. Princeton: Princeton University Press.

Wallcraft, Jan; Schrank, Beate; Amering, Michaela (eds.) (2009), Handbook of Service User Involvement in Mental Health Research. West Sussex: Wiley-Blackwell.

Wittgenstein, Ludwig (2001), Tractatus Logico-Philosophicus. London/New York: Routledge [orig. 1921].

Whitaker, Robert (2010), Anatomy of an Epidemic. Magic Bullets, Psychiatric Drugs, and the Astonishing Rise of Mental Illness in America. New York: Broadway Books. WHO - World Health Organization (2017), "Depression”. Accessed on 22.03.2018, at http://www.who.int/mediacentre/factsheets/fs369/en/.

\section{Tiago Pires Marques}

Centro de Estudos Sociais da Universidade de Coimbra

Colégio de S. Jerónimo, Largo D. Dinis, Apartado 3087, 3000-995 Coimbra, Portugal

Contacto: tmarques@ces.uc.pt 


\section{Doença e política do sofrimento social: para uma agenda de investigação crítica nos estudos da saúde e da ciência}

Este artigo analisa alguns dos problemas emergentes na interseção entre os campos dos estudos da saúde e da ciência. Baseando-se em perspetivas críticas, nomeadamente na história social, nos estudos pós-coloniais e na investigação colaborativa, defende-se a necessidade de fundar a investigação em formas históricas concretas de sofrimento social.

Esta estratégia implica uma abordagem em várias escalas que considerem: 1) o sofrimento individual e a doença experienciados em interações sociais; 2) as traduções por peritos, institucionalmente legitimadas, do sofrimento na doença; e 3 ) as racionalidades políticas, desenvolvidas por atores locais e globais, que contribuem para a criação de ambientes sociais de saúde e doença. Embora estas propostas teóricas sejam principalmente ilustradas com exemplos derivados do campo específico da saúde mental, argumenta-se que as suas implicações podem ser aplicadas num domínio mais vasto de temas relacionados com questões de saúde e ciência.

Palavras-chave: cuidados de saúde; doença; governação em saúde; saúde mental; sociologia da saúde; sofrimento.
Maladie et politique de la souffrance sociale: pour un agenda de recherche critique dans les études de la santé et de la science

Cet article aborde quelques-uns des problèmes émergents à l'intersection entre les domaines des études de la santé et de la science. Reposant sur des points de vue critiques, notamment sur l'histoire sociale, sur les études postcoloniales et sur la recherche collaborative, nous y défendons le besoin de faire reposer la recherche sur des formes historiques concrètes de souffrance sociale.

Cette stratégie implique une approche à divers échelons qui tiendront compte de: 1) la souffrance individuelle et la maladie vécues en interactions sociales; 2) les interprétations par des experts institutionnellement reconnues de la souffrance dans la maladie; et 3 ) les rationalités politiques, développées par des acteurs locaux et globaux, qui contribuent à la création d'environnements sociaux de santé et de maladie. Bien que ces propositions théoriques soient principalement illustrées comme des exemples découlant du domaine spécifique de la santé mentale, nous soutenons que leurs implications peuvent être appliquées à un champ plus vaste de thèmes ayant trait à des questions de santé et de sciences. Mots-clés: gouvernance de la santé; maladie; santé mentale; sociologie de la santé; soins de santé; souffrance. 